\title{
$\ll$ Research Note» \\ Cloning and Expression of Cellular Glutathione Peroxidase (GPX1) in Japanese Quail (Coturnix japonica)
}

\author{
Sopon Wilaison ${ }^{1,2}$ and Makoto Mori ${ }^{1,2}$ \\ ${ }^{1}$ Faculty of Agriculture, Shizuoka University, Shizuoka 422-8529, Japan \\ ${ }^{2}$ The United Graduate School of Agricultural Science, Gifu University, Gifu 501-1193, Japan
}

\begin{abstract}
Glutathione peroxidase 1 (cellular glutathione peroxidase, EC 1.11.1.9 (GPX1)) is an antioxidant enzyme that plays an important role in scavenging reactive oxygen species to protect cells from oxidative damage. To clone the quail GPX1, total RNA was extracted from mature female quail liver. Degenerated primers were designed based on conserved sequences among five species (human, monkey, cattle, rat, and mouse) to amplify the quail fragment GPX1 with reverse transcription polymerase chain reaction. The cDNA sequence of partial Japanese quail GPX1 is 212 nucleotides in length. The rapid amplification of cDNA ends system ( $5^{\prime}$ and $3^{\prime}$ RACE) was used to obtain the full-length Japanese quail GPX1 cDNA. The 843-nucleotide quail GPX1 cDNA contains a 153 amino acid open reading frame, a 7 bp 5'-untranslated region, and a 377 bp 3'-untranslated region containing the poly A tail. It contains putative selenocysteine residue which is encoded by an unusual stop codon TGA. Comparison of amino acid sequences showed that Japanese quail GPX1 shares $65-74 \%$ identity with GPX1 of other animals, suggesting that our clone is an authentic member of GPX1. GPX1 mRNA was expressed in all tissues examined including kidney, adrenal gland, liver, small follicle, small intestine, heart, and breast muscle; the highest level was detected in liver. This quail GPX1 cDNA will provide a tool for further studies of GPX1 expression in the quail.
\end{abstract}

Key words: antioxidant enzyme, cellular glutathione peroxidase, Japanese quail, mRNA expression, selenocysteine

J. Poult. Sci., 46: 52-58, 2009

\section{Introduction}

Glutathione peroxidase (GPX) is a generic name for a family of multiple isozymes. There are four known GPXs that contain selenocysteine at the active site classical or cellular GPX (GPX-1; EC 1.11.1.9), gastrointestinal GPX (GPX-2), plasma GPX (GPX-3), and phospholipid GPX (GPX-4). Additionally, at least two other proteins (GPX5, GPX6) have over 40\% sequence identity to cellular GPX but do not contain selenocysteine (Arthur, 2000; Herbette et al., 2007). In mammals, GPX together with superoxide dismutase (EC 1.15.1.1) and catalase (EC 1.11.1.6) constitutes an enzymatic antioxidant system which recycles reactive oxygen species (ROS) and limits their toxicity. ROS are generated as byproducts of aerobic metabolism and include molecules such as superoxide anions $\left(\mathrm{O}_{2}{ }^{-}\right)$, hydroxy radicals $\left(\mathrm{OH}^{-}\right)$, and hydroperoxides $\left(\mathrm{H}_{2} \mathrm{O}_{2}\right)$. ROS can lead to oxidative damage to proteins, nucleic acids, and lipids, resulting in cellular dysfunction (Fang et al., 2002). The damage induced by ROS is a main source of oxidative stress in living organisms (Han et al., 2005). GPX

Received: July 16, 2008, Accepted: September 29, 2008

Correspondence: Prof. M. Mori, Faculty of Agriculture, Shizuoka University, Shizuoka 422-8529, Japan.

(E-mail: acmmori@agr.shizuoka.ac.jp) plays an important role in cellular antioxidant defense by reducing $\mathrm{H}_{2} \mathrm{O}_{2}$ or various hydroperoxides using glutathione as a reducing agent to form water or corresponding alcohols respectively (Herbette et al., 2007).

Poultry are an important food resource for humans. They have high production efficiency and are improved continuously. That means they have high metabolic rates with ROS that are generated as byproducts of aerobic metabolism (Boveris and Chance, 1973). Thus, antioxidant defense systems are important to the health status of poultry and consequently to their productivity. Cellular glutathione peroxidase or GPX1 was the first identified selenoprotein (Rotruck et al., 1976) and is the most abundant biochemical form of body selenium (Se) (Behne and Wolters, 1983). It has been widely considered to be a major antioxidant enzyme that plays an important role in protecting cells from attack by ROS (Lei and Cheng, 2005). There are no reports on the nucleotide sequence of GPX1 in any avian species. Japanese quail is an important agricultural species for meat and egg production in many countries, and is also a useful model for the extrapolation of data to chickens and other commercially important poultry species (Jones, 1996). Therefore, it is appropriate to determine the nucleotide sequence of the GPX1 gene in Japanese quail.

In this study, we first cloned and characterized GPX1 
cDNA from the liver of Japanese quail. Then the GPX1 mRNA expression was examined in various tissues of the quail.

\section{Materials and Methods}

\section{RNA Isolation and First-Strand cDNA Synthesis}

Total RNA was extracted from mature female quail liver with RNAiso (Takara Bio, Japan) according to the manufacturer's instructions. The concentration of total RNA was estimated by measuring UV light absorbance at $260 \mathrm{~nm}$ using a spectrophotometer (Gene Quant; Pharmacia Biotech, Uppsala, Sweden). The first-strand cDNA was synthesized from $2 \mu \mathrm{g}$ of total RNA using SuperScript $^{\mathrm{TM}}$ First-Strand Synthesis System for RT-PCR kit (Invitrogen, CA, USA) according to the manufacturer's instructions.

\section{Cloning of Quail GPX1}

Full-length GPX1 of Japanese quail was obtained by reverse transcription polymerase chain reaction (RT-PCR), and by $3^{\prime}$ and $5^{\prime}$ rapid amplification of cDNA (RACE). Degenerated primers were designed based on highly conserved GPX1 nucleotide sequences of human (GenBank accession number: NM000581), mouse (NM008160), rat (NM030826), monkey (AB120997) and cattle (BC149308), which were compared using the CLUSTAL-W multiple alignment algorithm (http: //align.genome.jp/). The primers of QGPX1-F1 or QGPX1-F2, and those of QGPX1-R1 (Table 1), were used to amplify the first Japanese quail GPX1 cDNA fragment. All PCR amplifications were performed in a reaction mixture containing ExTaq polymerase (Takara Bio, Japan) on a TaKaRa PCR thermal cycler. PCR reactions were performed after $1 \mathrm{~min}$ of preparatory denaturation at $94^{\circ} \mathrm{C}$ as follows: 35 cycles of denaturation at $94^{\circ} \mathrm{C}$ for $30 \mathrm{sec}$, annealing at $51^{\circ} \mathrm{C}$ for $30 \mathrm{sec}$, and elongation at $72^{\circ} \mathrm{C}$ for $30 \mathrm{sec}$, followed by a $1 \mathrm{~min}$ extension at $72^{\circ} \mathrm{C}$ and cooling to $4^{\circ} \mathrm{C}$. The PCR products were subjected to agarose gel electrophoresis, and the band of the expected size was purified using the Rapid PCR Purification System (Marligen Biosciences, MD, USA) according to the manufacturer's instructions. Purified DNA was subcloned into pT7 Blue T-Vector (Novagen, WI, USA) using the TA Cloning Kit (Invitrogen, CA, USA) and se- quenced by dye-terminator chemistry on an Applied Biosystems Model 310 sequencer using the dideoxy-mediated chain-termination method (Sanger et al., 1977).

Based on the partial sequence information of Japanese quail GPX1 cDNA, new primers were designed to amplify the $3^{\prime}$ end and $5^{\prime}$ end of Japanese quail GPX1 (Table 1). $3^{\prime}$-RACE (rapid amplification of $3^{\prime}$ cDNA end) was performed using the $3^{\prime}$ RACE System for Rapid Amplification of cDNA Ends (Invitrogen, CA, USA), and 5'. RACE (rapid amplification of $5^{\prime}$ cDNA end) was performed using the $5^{\prime}$ RACE System for Rapid Amplification of cDNA Ends, Version 2.0 (Invitrogen, CA, USA). To amplify the $3^{\prime}$ end of quail GPX1, cDNA was made from messenger RNA by reverse transcription with SuperScrip II reverse transcriptase primed with Oligo-dT adapter primer (AP solution). Gene-specific primer QGPX1-3 RACE-F1 and Universal Amplification Primer (UAP) were used to amplify the $3^{\prime}$ end. The PCR reaction conditions were the same as those described above, except the annealing temperature was changed to $62^{\circ} \mathrm{C}$. To amplify the $5^{\prime}$ end, first-strand cDNA was synthesized using gene-specific primer 1 (GSP1). PCR amplified dC-tailed cDNA using Abridged Anchor Primer (AAP) and gene-specific primer 2 (GSP2). The primary PCR product was reamplified using UAP and gene-specific primer 3 (GSP3). The PCR reaction conditions were the same as those described above, except the annealing temperature was changed to $58-62^{\circ} \mathrm{C}$. Amplified 3'- and 5'-RACE PCR products were separated by $1 \%$ agarose gel electrophoresis. The bands of expected size were eluted from the gel using the Rapid Gel Extraction System (Marligen Biosciences, MD, USA) according to the manufacturer's instructions and sequenced as described above.

\section{Sequence Analysis}

The GPX1 gene sequence was analyzed and compared using the BLAST search program of GenBank (http: // www.ncbi.nlm.nih.gov/blast/Blast.cgi). A multiple sequence alignment of the GPX1 gene was created using CLUSTAL W (Thomson et al., 1994). Phylogenetic analysis of the aligned sequences was performed using the neighbor-joining method of the MEGA 4.0 program (Tamura et al., 2007). Bootstrap analysis (500 bootstrap

Table 1. Oligonucleotides used in the study

\begin{tabular}{|c|c|c|}
\hline Name & Oligonucleotide sequence & Length \\
\hline QGPX1-F1 & 5'-CAGTTYGGRCAYCAGGAGAA-3' & $20 \mathrm{nt}$ \\
\hline QGPX1-F2 & 5'-SAAYSARGAGATYCTGAA-3' & $18 \mathrm{nt}$ \\
\hline QGPX1-R1 & 5'-CAGGAACTTCTCRAAGYTCCAGG-3' & $23 \mathrm{nt}$ \\
\hline QGPX1-3RACE-F1 & 5'-CTGTTCGCCCTTCCTGAGAGA-3' & $21 \mathrm{nt}$ \\
\hline GSP1 & 5'-TCTCTCAGGAAGGCGAACAG-3' & $20 \mathrm{nt}$ \\
\hline GSP2 & 5'-GTTCACCTCGCACTTTTCG-3' & $19 \mathrm{nt}$ \\
\hline GSP3 & 5'-TGAAGTTGGGTTTGAAGCCG-3' & $20 \mathrm{nt}$ \\
\hline GPX1-F & 5'-CAGTTCGGGCATCAGGAGAA-3' & $20 \mathrm{nt}$ \\
\hline GPX1-R & 5'-CGAGGAACTTGCTCGAAAGTTACCAGG-3' & $27 \mathrm{nt}$ \\
\hline$\beta$-actin-F & 5'-ACAATGTACCCTGGCATTGCT-3' & $21 \mathrm{nt}$ \\
\hline$\beta$-actin- $\mathbf{R}$ & 5'-TCGTCTTGTTTTATGCGCATT-3' & $21 \mathrm{nt}$ \\
\hline
\end{tabular}


replications) was employed to test the reliability of the topologies of the phylogenetic trees in the present study. The homology between the Japanese quail GPX1 amino acid sequence and other GPX1 amino acid sequences was calculated by using the FASTA program (http: //www. ebi.ac.uk/fasta33/). The isoelectric point (pI) and molecular weight $\left(\mathrm{M}_{\mathrm{w}}\right)$ of Japanese quail GPX1 protein were calculated using the ExPASy program (www.expasy.org/ tools/pi_tool.html).

\section{Expression Analysis of GPX1 mRNA in Tissues}

PCR assays were designed to normalize GPX1 gene expression levels to $\beta$-actin mRNA. One microliter of first-strand cDNA was used for PCR amplification. The total reaction volume was $50 \mu l$ containing $1 \mu l$ of cDNA, 10 pmol of each forward and reverse primer, $4 \mu l$ of dNTPs (2.5 mM each), $5 \mu l$ of 10x PCR buffer and $1.25 \mathrm{u}$ of Taq DNA-polymerase (Takara Bio, Japan). GPX1 mRNA was amplified using the GPX1-F and GPX1-R primers; $\beta$-actin mRNA was amplified using the $\beta$-actin-F and $\beta$-actin-R primers. PCR reactions for GPX1 were performed after $1 \mathrm{~min}$ of preparatory denaturaion at $94^{\circ} \mathrm{C}$ as follows: 40 cycles of denaturation at $94^{\circ} \mathrm{C}$ for $30 \mathrm{sec}$, annealing at $62^{\circ} \mathrm{C}$ for $30 \mathrm{sec}$, and elongation at $72^{\circ} \mathrm{C}$ for 30 sec, followed by a $1 \mathrm{~min}$ extension at $72^{\circ} \mathrm{C}$ and cooling to $4^{\circ} \mathrm{C}$. PCR reactions for $\beta$-actin were performed after 1 min of preparatory denaturation at $94^{\circ} \mathrm{C}$ as follows: 30 cycles of denaturation at $94^{\circ} \mathrm{C}$ for $30 \mathrm{sec}$, annealing at $58^{\circ} \mathrm{C}$ for $30 \mathrm{sec}$, and elongation at $72^{\circ} \mathrm{C}$ for $30 \mathrm{sec}$, followed by a $1 \mathrm{~min}$ extension at $72^{\circ} \mathrm{C}$ and cooling to $4^{\circ} \mathrm{C}$. These numbers of PCR cycles ensured quantification within the exponential phase of amplification. Equal amounts of RT-PCR reactions $(9 \mu l)$ were loaded on standardized $1 \%$ agarose gels containing $0.1 \mu \mathrm{l} / \mathrm{ml}$ ethidium bromide. The gel images were digitalized by a gel documentation system (Kodak Laboratories, NY, USA) and GPX1 mRNA bands were quantified by NIH Image J software. GPX1 mRNA levels were normalized to the $\beta$-actin mRNA.

\section{Results}

\section{Cloning and Analysis of Japanese Quail GPX1 cDNA}

The nucleotide and predicted amino acid sequences of the cDNA shown in Fig. 1 are presumed to represent Japanese quail GPX1. The putative transcription initiation site found by $5^{\prime}$-RACE is located at nucleotide (nt) position 1. The initiation site of translation was placed at nt 8 , inferred by conceptual translation of the cDNA sequence in all tree reading frames and by alignment with the known sequences of GPX1 proteins available in GenBank. The putative Japanese quail GPX1 cDNA (Fig. 1) is found to contain a $459 \mathrm{bp}$ open reading frame (ORF) and an in-frame TAA stop codon at the $3^{\prime}$-end of the coding region. The ORF is flanked by a $359 \mathrm{bp} 3^{\prime}$ untranslated region followed by the putative poly (A) tail. Two polyadenylation consensus sequences ( $5^{\prime}$-AATAAA$3^{\prime}$ ) are located between the stop codon and the poly (A) tail. As shown in Fig. 1, the deduced GPX1 is composed of 153 amino acid residues. The theoretical molecular weight $\left(\mathrm{M}_{\mathrm{w}}\right)$ of the protein sequence is calculated to be $16.72 \mathrm{kDa}$ and the isoelectric point $(\mathrm{pI})$ to be 8.69. The predicted amino acid sequence exhibited characteristic glutathione peroxidase signature residues LGFPCNQF (residues 64-71). Japanese quail GPX1 contained two selenocysteine residues (residues 39 and 148) identified as Selenocysteine (U). The coding region of the Japanese quail GPX1 cDNA shares 65-74\% identity with the GPX 1 sequences from rat, mouse, dog, human, monkey, rabbit, pig, and cattle (Table 2).

Figure 2 shows the alignment of the Japanese quail GPX1 deduced amino acid sequence with this of the GPX1 of other animals. All GPX1 cDNAs had a TGA codon that encodes $U$ which is conserved in all animals. Characteristic glutathione peroxidase signature residues (LGFPCNQF) are conserved in Japanese quail. Residues constituting the catalytic triad (U-39, Q-74 and W-142) are also conserved in Japanese quail GPX. The conserved sequences correspond largely to those parts of the protein that form the active site in bovine GPX (Epp et al., 1983). These indicated that essential catalytic properties are similar between mammalian and Japanese quail GPX1.

For phylogenetic characterization, the Japanese quail GPX1 protein sequence was compared to several GPX1 sequences from various organisms. A phylogenetic tree was constructed by the neighbor-joining method using the MEGA 4 program. Phylogenetic analysis showed that Japanese quail GPX1 is clustered with the GPX1 of other organisms (Fig. 3).

\section{GPX1 mRNA Expression Analysis}

To examine the GPX1 transcription levels in Japanese quail, the GPX1 mRNA expression pattern was investigated in different tissues by RT-PCR using gene-specific primers (Fig. 4). GPX1 mRNA was widely expressed in all tissues examined including kidney, adrenal gland, liver, small intestine, heart, and breast muscle. The highest expression was observed in liver, and the lowest in the small follicle (Fig. 4).

\section{Discussion}

In this study, the full-length Japanese quail GPX1 gene sequence was cloned and characterized from the liver of mature female quail. The Japanese quail GPX1 protein contained an amino acid selenocysteine encoded by the opal termination codon (TGA). This is consistent with the fact that GPX belongs to a group of proteins known in mammals to contain selenocysteine (Sukenaga et al., 1987). This unusual amino acid occurs at the active site of GPX and other proteins known as selenoproteins such as thioredoxin reductase and selenoprotein $\mathrm{P}$ (Hoffmann et al., 2007). Phylogenetic analysis showed that the Japanese quail GPX1 is grouped with other GPX1. Hence, the identification of glutathione peroxidase residue LAFPCNQF, the presence of the conserved selenocysteine residue, and phylogenetic grouping with several GPX1 in the currently described protein suggested that this protein is GPX1.

To observe the distribution of this gene in Japanese 
1 GGCAGCAATGGCAGCAAAGGGGCTGGCGGGGATCGTGGCGCGGCCGCTGGGCGCAGCGGAG 61

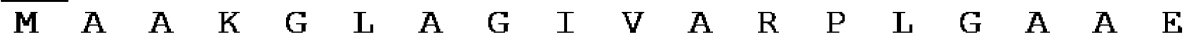

62 CCGCTGGCGCTGGATTCGCTGCGGGGCAAAGTGCTGCTGGTCGTCAACGTGGCGTCGCTT 121
$\begin{array}{llllllllllllllllllll}\text { P } & \text { L } & \text { A } & \text { L } & \text { D } & \text { S } & \text { L } & \text { R } & \text { G } & \text { K } & \text { V } & \text { L } & \text { L } & \text { V } & \text { V } & \text { N } & \text { V } & \text { A } & \text { S } & \text { L }\end{array}$

122

TGAGGCACCACCACGCGCGATTTCCTGCAGCTCAACGAGCTGCAGCAGCGCTACGGGCCC 181 \begin{tabular}{lllllllllllllllllllll}
\hline & $G$ & $T$ & $T$ & $T$ & $R$ & $D$ & $F$ & L & $Q$ & L & N & E & L & $Q$ & $Q$ & $R$ & $Y$ & $G$ & $P$
\end{tabular}

182

CGCGGGCTGCGTGTGCTCGGCTTCCCCTGCAACCAGTTCGGGCATCAGGAGAACGCCACC 241

$\begin{array}{lllllllllllllllllllll}R & G & \text { L } & \text { R } & \text { V } & \text { L } & G & \text { G } & \text { F } & \text { P } & \text { C } & \text { N } & \text { Q } & \text { F } & \text { G } & \text { H } & \text { Q } & \text { E } & \text { N } & \text { A } & \text { T }\end{array}$

242 AACGAGGAGATCCTGCGCTCGCTGGAGTTCGTGCGGCCCGGCAACGGCTTCAAACCCAAC 301

$\begin{array}{llllllllllllllllllll}\mathbf{N} & \mathrm{E} & \mathrm{E} & \mathrm{I} & \mathbf{L} & \mathrm{R} & \mathbf{S} & \mathbf{L} & \mathrm{E} & \mathrm{F} & \mathrm{V} & \mathrm{R} & \mathrm{P} & \mathbf{G} & \mathbf{N} & \mathrm{G} & \mathrm{F} & \mathrm{K} & \mathrm{P} & \mathbf{N}\end{array}$

302 TTCACCATGTTCGAAAAGTGCGAGGTGAACGGGAAGGGAGCCCACCCGCTGTTCGCCTTC 361

$\begin{array}{llllllllllllllllllll}\text { F } & \text { T } & \text { M } & \text { F } & \text { E } & \text { K } & \text { C } & \text { E } & \text { V } & \text { N } & \text { G } & \text { K } & \text { G } & \text { A } & \text { H } & \text { P } & \text { L } & \text { F } & \text { A } & \text { F }\end{array}$

362 CTGAGAGAGGCGCTGCCGTTCCCCCACGACGACCCGTCGGCGCTGATGACCAACCCGCAG 421 $\begin{array}{lllllllllllllllllllll}\mathbf{L} & \mathrm{R} & \mathrm{E} & \mathbf{A} & \mathbf{L} & \mathrm{P} & \mathrm{F} & \mathrm{P} & \mathrm{H} & \mathrm{D} & \mathbf{D} & \mathrm{P} & \mathrm{S} & \mathbf{A} & \mathbf{L} & \mathbf{M} & \mathbf{T} & \mathbf{N} & \mathrm{P} & \mathrm{Q}\end{array}$

422 TACATCATCTGGTACCCCCGTAGTGCCTGAACGACGTCTACCTGGTAACTTTCGAGCAAG 481 $\begin{array}{llllllllllllllllllll} & Y & I & I & W & Y & P & R & S & A & U & T & T & S & T & W & \end{array}$

482 TTCCTCGTAGACCCCGAGGGCGTCCCCTTCCGCCGCTACAGCCGCCACTTCGAGACCATC 541

542 AAACTGCAGGACGACATCGAGCTGCTGCTCCGGAAGGTGCCCAAGGAGGCTCTGCAATAA 601

602 AGGAAAGCCTGCAGCTCTGTTATATGAAGGGCTGCTGCTCCGGCTGATCTCCCACCATCC 661

662 GCACATGCTTTGCTTGTGACGGCGCATCTTCCAAATCCTCGAAGTGTGCCCGATGTTTTC 721

722 AAAGCTGCGTGTGAAATGTTTGGGGGATCTCAGCTTGGGGCAGCAGCCTATGGGGCTGGT 781

782 GATGGCATGGGAGTCTATGAATAAAGACCAAATCTATCTGCAAAAAAAAAAAAAAAAAAA 841

842 AA 843

Fig. 1. The nucleotide sequence of cDNA for Japanese quail GPX1 and its amino acid sequence. The translation initiation (ATG) and stop (TAA) codons are double-underlined. The TGA codon that is assumed to encode selenocysteine (U) is bold and underlined. The motifs of polyadenylation signal are also bold. The data have been submitted to GenBank under the accession number AB371709.

Table 2. Homology between Japanese quail and other GPX1 amino acid sequences

\begin{tabular}{lcc}
\hline \hline $\begin{array}{l}\text { Sequence from } \\
\text { EMBL GenBank } \\
\text { (accession number) }\end{array}$ & $\begin{array}{c}\text { Number of } \\
\text { amino acids }\end{array}$ & $\begin{array}{c}\text { Percentage } \\
\text { identity* }\end{array}$ \\
\hline Rat (P04041) & 201 & 73.9 \\
Dog (Q6PXE0) & 145 & 73.9 \\
Mouse (Q5RJH8) & 201 & 73.1 \\
Human (P07203) & 203 & 71.3 \\
Pongo (Q4AEI3) & 201 & 71.3 \\
Pig (Q8MJ14) & 206 & 68.1 \\
Rabbit (P11909) & 200 & 65.8 \\
Cattle (P00435) & 205 & 65.1 \\
\hline
\end{tabular}

* Percentage amino acid identity is calculated by the FASTA program.

quail, GPX1 mRNA expression was studied by RT-PCR using $\beta$-actin as a control. Expression was found in all tissues examined and was highly expressed in liver. This observation agrees with previous studies of mammalian species, such as rat (Ho and Howard, 1992) and Japanese monkey (Fukuhara and Kageyama, 2003), that showed that GPX1 is widely expressed in many tissues and highly expressed in liver. The GPX1 mRNA was especially abundant in tissues known to have high metabolic activity. This localization is consistent with a role for this protein in removing ROS generated through internal body metabolism. Its expression in many tissues suggests that this antioxidant enzyme may be important in providing local cellular protection. Ojano-Dirain et al. (2004) have reported that $\mathrm{H}_{2} \mathrm{O}_{2}$ levels are higher in the duodenal mitochondria of low-feed-efficiency broiler breeders than in high-feed-efficiency broiler breeders. This may indicate that the relationship between $\mathrm{H}_{2} \mathrm{O}_{2}$ and antioxidant enzyme is involved in the phenotypic expression of feed efficiency in broiler breeders. GPX1 is a major and ubiquitously expressed antioxidant enzyme present in cytosol and mitochondria. It is involved in the detoxification of 


\begin{tabular}{|c|c|}
\hline Rat & ISAARLSAVAQS-----TVYAFSARPLAGGEPVSLGSLRGKVLLIENVASLUGTTTRDYT \\
\hline Mouse & ICAARLSAAAQS-----TVYAFSARPLTGGEPVSLGSLRGKVLLIENVASL UGTTIRDYT \\
\hline Human & САARLAAAAAA---AQSVYAFSARPLAGGEPVSLGSLRGKVLLIENVASLUGTTVRDYT \\
\hline Monkey & MCAARLVAAA-----AQSVYSFSARPLAGGEPVSLGSLRGKVLLI ENVASLUGTTVRDYT \\
\hline Rabbit & ----QSVYSFSAHPLAGGEPVNLGSLRGKVLLIENVASLUGTTVRDYT \\
\hline Cattle & MCAAQRSAAALAAAAPRTVYAFSARPLAGGEPFNLSSLRGKVLLIENVASL UGTTVRDYT \\
\hline Pig & MCAAQRSAAALAAVAPRSVYAFSARPLAGGEPISLGSLRGKVLLIENVASLUGTTVRDYT \\
\hline Quail & -----------ARPLGAAEPLALDSLRGKVLLVVNVASLUGTTTRDFL \\
\hline
\end{tabular}

Rat

Mouse

EMNDLQKRLGPRGLVVLGFPCNQFGHQENGKNEEILNSLKYVRPGGGFEPNFTLFEKCEV 115 Human

Monkey EMNDLQKRLGPRGLVVGFPCNQFGHQENGKNEEILNSLKYVRPGGGFEPNFTLFEKCEV 115 QMNELQRRLGPRGLVVLGFPCNQFGHQENAKNEEILNSLKYVRPGGGFEPNEMLFEKCEV 117 Rabbit QMNELQRRLGPRGLVVLGFPCNQFGHQENAKNEEILNSLKYVRPGGGFEPNFMLFEKCEV 115 Cattle Pig Quail QMNELQERLGPRALVVLGFPCNQFGHQENAKNEEILNSLKYVRPGGGFEPNEMLFQKCEV 114 QMNDLQRRLGPRGLVVLGFPCNQFGHQENAKNEEIPNCLKYVRPGGGFEPNFMLFEKCEV 120 QMNELQRRLGPRGLVVLGFPCNQFGHQENAKNGEILNCLKYVRPGGGFEPNFMLFEKCEV 120 QLNELQQRYGPRGLRVIGFPCITOFGHQENATNEEILRSLEFVRPGNGFKPNFTMFEKCEV 107

Rat NGEKAHPLFTFLRNALPAPSDDPTALMTDPKYI I WSPVCR-NDISWNEEKFLVGPDGVPV 174 Mouse NGEKAHPLFTFLRNALPTPSDDPTALMTDPKYI I WSPVCR-NDIAWNFEKFLVGPDGVPV 174 Human Monkey Rabbit NGAGAHPLFAFLREALPAPSDDATALMTDPKLIT WSPVCR-NDVAWNFEKFLVGPDGVPL 176 NGAGAHPLFAFLREALPAPSDDATALMTDPKLIT WSPVCR-NDVAWNFEKFLVGPDGVPL 174 NGAKASPLFAFLREALPPPSDDPTALMTDPKF IT WCPVCR-NDVSWSFEKFLVGPDGVPV 173 Cattle Pig Quail NGEKAHPLFAFLREVLPTPSDDATALMTDPKF ITWSPVCR-NDVSWNEEKFLVGPDGVPV 179 NGANAHPLFAFLREALPTPSDDATALMTDPKFIT WSPVCR-NDIAWNEEKFLVGPDGVPL 179 NGKGAHPLFAFLREALPFPHDDPSALMTNPQYI I WYPRSAUTTSTW-------_------ 153

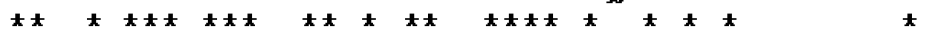

Rat RRYSRRFRTIDIEPDIEALLSKQPSNP 201 Mouse $\quad$ RRYSRRFRTIDIEPDIETLLSQQSGNS 201 Human RRYSRRFQTIDIEPDIEALLSQGPSCA 203 Monkey RRYSRRFQTIDIEPDIEALLSQGPSCA 201 Rabbit RRYSRRPTIDIEPDIQALLSKGSGGA 200 Cattle RRYSRRFLTIDIEPDIETLLSQGASA - 205 Pig RRYSRRELTIDIEPDIEALLSQEPSSA 206

Quail

Fig. 2. Comparison of GPX1 amino acid sequences of Japanese quail and GPX1 of the human (accession no. NM000581), monkey (AB120997), rat (NM030826), mouse (NM008160), cattle (BC149308), pig (AF532927) and rabbit (NM001085444). Dashes indicate the amino acid gaps that are necessary to align these sequences. The conserved residues in all sequences are indicated by an asterisk $(*)$. Glutathione peroxidase signature residues are bold and underlined. The catalytically important residues are bold.

hydrogen and lipid peroxide (Brigelius-Flohe and Flohe, 2003). It has been widely considered a major antioxidant enzyme that plays an important role in protecting cells from attack by ROS (Lei and Cheng, 2005). De Hann et al. (1998) demonstrated a role for GPX1 in protecting against oxidative stress by showing that Gpx1 -/- mice are highly sensitive to the oxidant paraquat. Liddell et al. (2006) demonstrated that GPX1 contributes to the rapid clearance of $\mathrm{H}_{2} \mathrm{O}_{2}$ by mouse astrocytes and that both GPX 1 and a high concentration of glutathione are required to protect these cells from iron-dependent peroxide damage. These findings reinforce the notion that this antioxidant enzyme may be essential for all tissues.

In addition, glutathione peroxidases have been proposed as possible tools for bio-monitoring environmental toxicants and stressors. Their differential expression as compared to normal expression pattern indicates exposure to cellular stress and adverse cellular effects, thus serving as biomarkers of these effects (Li et al., 2003; Zhang et al., 2004).

In industrial poultry production, while marked improvements have been made in both high production rates (meat and eggs) and feed efficiency (poultry), high incidences of mortality and metabolic disorders threaten the viability of the industry. Metabolic disorder is associated with increased metabolism, rapid growth rate or high egg production that results in the failure of a body system because of an increased workload on that organ or system 


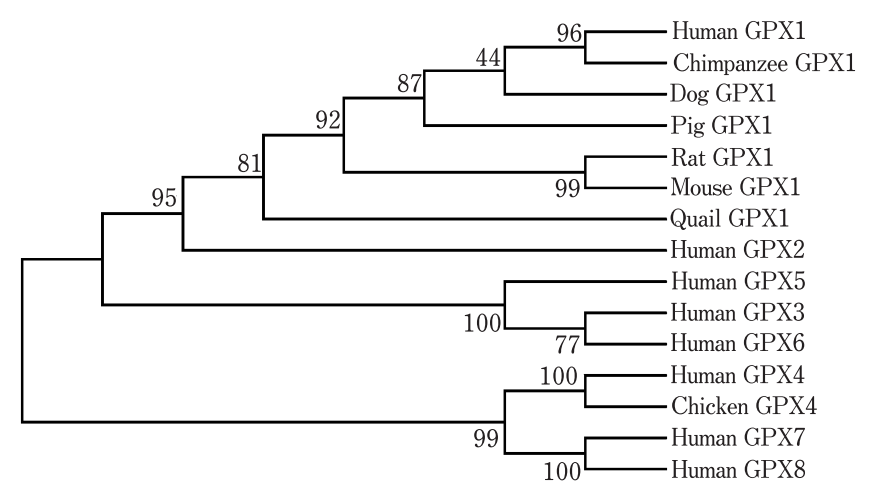

Fig. 3. The phylogenetic tree of GPXs constructed from the protein-encoding cDNA sequences by the neighbor-joining method using the MEGA 4 program. Bootstrap value (\%) obtained with 500 replicates is shown at each node.

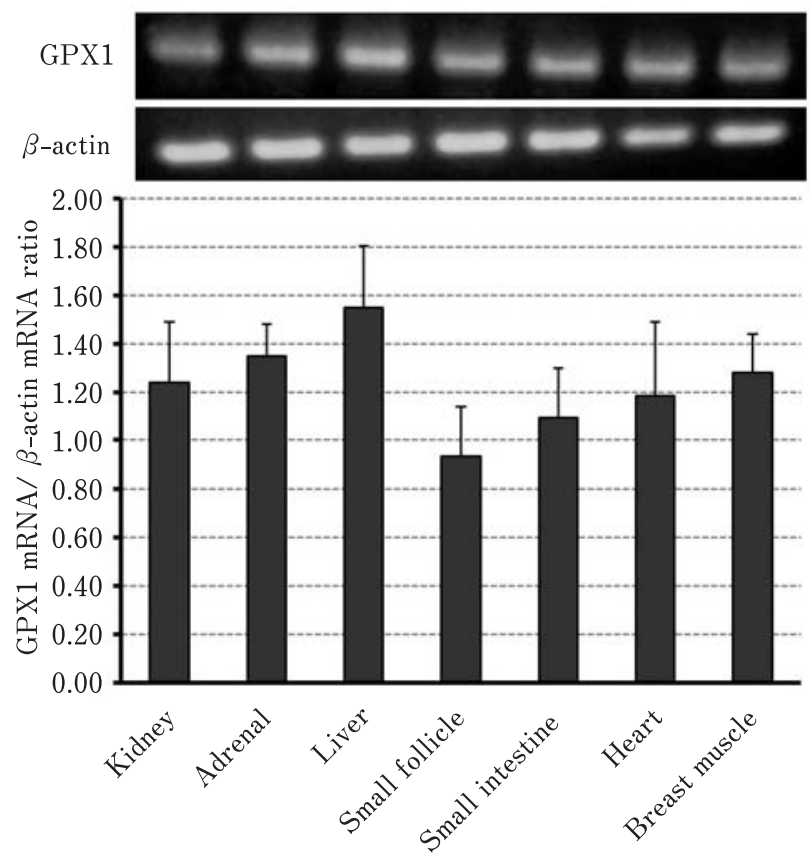

Fig. 4. RT-PCR detection of GPX1 and $\beta$-actin mRNA expression in various tissues of Japanese quail, including kidney, adrenal gland, liver, small follicle, small intestine, heart and breast muscle. Data are expressed as means \pm SD of 3 replications. Error bars indicate SD.

(Julian, 2005). Therefore, the study of the GPX1 gene at the molecular level as an antioxidant defense system may lead to a better understanding and solution of the problems confronting to poultry production in the future.

In this study, we determined the nucleotide sequence of GPX1 cDNA and presented the tissue distributions of GPX1 mRNA expression in Japanese quail. These data will be useful in further studies relating to GPX1 gene expression in Japanese quail.

\section{Acknowledgments}

We would like to thank Dr. Tomohiro Sasanami for technical assistance and Dr. Norio Kansaku (Laboratory of Animal Genetics and Breeding, Azabu University) for nucleotide sequencing.

\section{References}

Arthur JR. The glutathione peroxidases. Cellular and Molecular Life Science, 57: 1825-1835. 2000.

Behne D and Wolters W. Distribution of selenium and glutathione peroxidase in the rat. Journal of Nutrition, 113: 456461. 1983.

Boveris A and Chance B. The mitochondrial generation of hydrogen peroxide. Biochemistry, 134: 707-711. 1973.

Brigelius-Flohe $\mathrm{R}$ and Flohe $\mathrm{L}$. Is there a role of glutathione peroxidases in signaling and differentiation? Biofactors, 17: 93-102. 2003.

De Haan JB, Bladier C, Griffiths P, Kelner M, O'Shea RD, Cheung NS, Bronson RT, Silvestro MJ, Wild S, Zheng SS, Beart PM, Hertzog PJ and Kola I. Mice with a homozygous null mutation for the most abundant glutathione peroxidase, Gpx1, show increased susceptibility to the oxidative stressinducing agents paraquat and hydrogen peroxide. Journal of Biological Chemistry, 273: 22528-22536. 1998.

Epp O, Ladenstein R and Wendel A. The refined structure of the selenoenzyme glutathione peroxidase at $0.2-\mathrm{nm}$ resolution. European Journal of Biochemistry, 133: 51-69. 1983.

Fang YZ, Yang S and Wu G. Free radicals, antioxidants, and nutrition. Nutrition, 18: 872-879. 2002.

Fukuhara R and Kageyama T. Tissue distribution, molecular cloning, and gene expression of cytosolic glutathione peroxidase in Japanese monkey. Zoological Science, 20: 861868. 2003.

Han JY, Song KD, Shin JH, Han BK, Park TS, Park SH, Kim JK, Lillehoj HS, Lim JK and Kim H. Identification and characterization of the peroxiredoxin gene family in chickens. Poultry Science, 84: 1432-1438. 2005.

Herbette S, Roeckel-Drevet P and Drevet JR. Seleno-independent glutathione peroxidases: More than simple antioxidant scavengers. FEBS Journal, 274: 2163-2180. 2007.

Ho YS and Howard AJ. Cloning and characterization of the rat glutathione peroxidase gene. FEBS Letters, 301: 5-9. 1992.

Hoffmann PR, Hoge SC, Li PA, Hoffmann FW, Hashimoto AC and Berry MJ. The selenoproteome exhibits widely varying, tissue-specific dependence on selenoprotein $\mathrm{P}$ for selenium supply. Nucleic Acids Research, 35: 3963-3973. 2007.

Jones RB. Fear and adaptability in poultry: Insights, implications, and imperatives. World's Poultry Science Journal, 52: 131-174. 1996.

Julian RJ. Production and growth related disorders and other metabolic diseases of poultry - A review. Veterinary Journal, 169: 350-369. 2005.

Lei KG and Cheng WH. New roles for an old selenoenzyme: evidence from glutathione peroxidase-1 null and overexpressing mice. Journal of Nutrition, 135: 2295-2298. 2005.

Li WM, Yin DQ, Zhou Y, Hu SQ and Wang LS. 3,4-dichloroaniline-induced oxidative stress in liver of crucian carp (Carassius auratus). Ecotoxicology and Environmental Safety, 56: 251-255. 2003.

Liddell JR, Hoepken HH, Crack PJ, Robinson SR and Dringen 
R. Glutathione peroxidase 1 and glutathione are required to protect mouse astrocytes from iron-mediated hydrogen peroxide toxicity. Journal of Neuroscience Research, 84: 578586. 2006.

Ojano-Dirain CP, Iqbal M, Cawthon D, Swonger S, Wing U, Cooper $\mathrm{M}$ and Bottje W. Determination of mitochondrial function and site-specific defects in electron transport in duodenal mitochondria in broilers with low and high feed efficiency. Poultry Science, 83: 1394-1403. 2004.

Rotruck JT, Pope AL, Ganther HE, Swanson AB, Hafeman DG and Hoekstra WG. Selenium: biochemical role as a component of glutathione peroxidase. Science, 179: 588-590. 1973.

Sanger F, Nicklen S and Coulson AR. DNA sequencing with chain-terminating inhibitors. Biotechnology, 24: 104-108. 1977.
Sukenaga Y, Ishida K, Takeda U and Takagi K. cDNA sequence coding for human glutathione peroxidase. Nucleic Acids Research, 15: 7178. 1987.

Tamura K, Dudley J, Nei M and Kumar S. MEGA 4: Molecular evolutionary genetics analysis (MEGA) software version 4. Molecular Biology and Evolution, 24: 1596-1599. 2007.

Thompson DJ, Higgins DG and Gibson TJ. CLUSTAL W: improving the sensitivity of progressive multiple sequence alignment through sequence weighting. Nucleic Acids Research, 22: 4673-4680. 1994.

Zhang J, Shen H, Wang X, Wu J and Y. Xue. Effects of chronic exposure of 2,4-dichlorophenol on the antioxidant system in liver of freshwater fish Carassius auratus. Chemosphere, 55: 167-174. 2004. 